\title{
Modeling Three-Phase Transformers
}

\author{
I. F. Novais ${ }^{1}$, A. A. P. Junior ${ }^{1}$ and S. F. P. Silva ${ }^{1}$ \\ ${ }^{1}$ FEELT - College of Electrical Engineering \\ UFU, Federal University of Uberlandia \\ Santa Monica Campus - João Naves de Ávila, 2121 Uberlandia (Brazil) \\ Phone/Fax number: +55 34 32394733, e-mail: isabela_0405@hotmail.com, acriziomarjunior@gmail.com, \\ s.ferreiradepaula@ufu.br
}

\begin{abstract}
Transformers in electric power systems are of great importance, with significant effects on the distribution of electric energy. The modeling of this machine, considering the various usable connections, requires a more detailed analysis for better results. Thus, the objective of this work is to propose a three-phase transformer model including the neutral in the admittance matrices, the ground impedance, taps settings and also the magnetizing branch.
\end{abstract}

\section{Key words}

Three-phase transformers modeling, ground impedance, magnetizing branch, admittance matrix.

\section{Introduction}

Renewable energy sources have played an important role in solving the high energy consumption worldwide. In high-tech transmission systems requires more efficient transformers to reliably supply wind and solar energy. In electric power distribution systems, transformers are of fundamental importance, since they are responsible for the compatibility between the distribution voltage (medium voltage) and the supply voltage for the final customer (low voltage).

Together with the electric conductors, transformers are the means to conduct the energy between the source and the final consumption, that is, they are in series with the load. This means that all current flows through them, and consequently, the higher the resistance, the greater the joule loss $\left(\mathrm{RI}^{2}\right)$ due to its operation.

According to a study carried out by the Electric Energy Research Center (CEPEL), the losses of such machines add up to a daily average cost of US\$2,924,190.59, which corresponds to the order of 22,169.3 MWh of energy [1].Thus, the magnitude of these losses demonstrates that efficient transformers are an excellent decision for the conservation of precious energy sources and for the reduction of operational costs of the industry, while helping to preserve the environment.

Therefore, although well-known, transformers are an excellent opportunity to study with a view to identifying possibilities of savings or even recommendations as to the best technology to be used by these equipment's.

In the new electrical systems projects and in the evaluation of the existing ones, digital simulation is an essential tool for the engineer's work. However, due to the practicality of modeling and the smallest computational effort, the large electrical systems, for the most part, still use single-phase modeling for their simulation. This condition disregards the different types of connections, the couplings and the possible unbalances between the phases.

Current computer systems have processing and storage capabilities that enable three-phase simulation of large power systems. This property allows more precise studies to be carried out, but faces new obstacles, such as the difficulty of convergence of the algorithms, prepared for single-phase systems, and the adaptation of single-phase models to three-phase ones.

Three-phase transformers are present in all electrical power systems and have several primary and secondary connection options, grounding forms and voltage control.

In this context, the purpose of this paper is to present adaptations of the traditional two windings power transformer model, incorporating the neutral in the admittance matrices and considering the ground impedance, the possible taps and the magnetizing branch. In addition to the representation of these parameters, the study seeks to contribute to the achievement of more realistic models and contributing to more precise assessments of an electrical power system.

\section{Transformer Base Impedances}


Because the transformer played a fundamental role in the electrical systems, it always demanded the need to a representation by an electric circuit that translated the behavior of the voltages and currents in its entrance and exit. Together with the frequency domain representation, Charles P. Steinmetz [2] presented the mathematical modeling of a single-phase transformer, as shown in Figure 1. The Steinmetz equivalent applies to both single-phase transformers and one phase of a three-phase transformer bank.

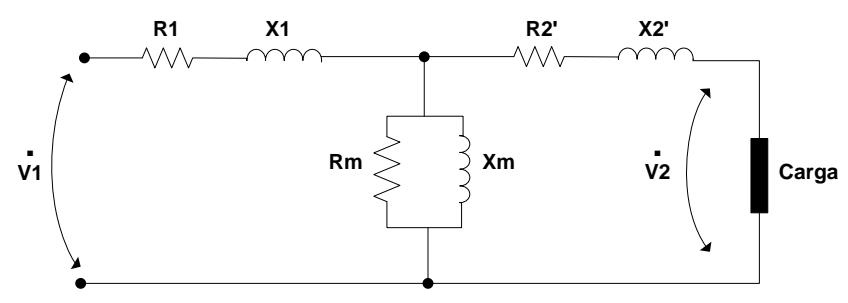

Figure 1. Steinmetz Equivalent Circuit.

The parameters of the Steinmetz circuit are obtained from the data of the transformer board and of two tests: noload and short-circuit [2].

The impedances of the primary side $\dot{Z}_{1}\left(R_{1}+j X_{1}\right)$, of the secondary referred to the primary $\dot{Z}_{2}\left(R_{2}^{\prime}+j X_{2}^{\prime}\right)$, of the magnetization branch $\dot{Z}_{M}\left(R_{m} / / j X_{m}\right)$ and their consequent admittances $\dot{Y}_{1}, \dot{Y}_{2}$ e $\dot{Y}_{M}$ constitute the basic parameters for the elaboration of the matrix between the primary busbar and the secondary busbar.

The mathematical procedure for obtaining these parameters is presented in the following sequence, considering the system per-unit $[\mathrm{pu}]$, where reference values of voltage $\left(V_{B}\right)$, current $\left(I_{B}\right)$, power $\left(S_{B}\right)$ and impedance $\left(Z_{B}\right)$ use the nominal (board) values of transformer.

The short-circuit test, in the case of two-winding transformers, is performed by short-circuiting the terminals of one of the windings, preferably the lower voltage one, to facilitate reading the voltage and current on the high side, and applying voltage at the rated frequency on the other winding until the nominal current is short-circuited [2]. This procedure makes it possible to calculate the short-circuit impedance, which characterizes the impedance between primary and secondary, consisting of a resistance in series with an inductive reactance, which in turn, indicates the joule losses due to the nominal current flow through the windings and the losses by dispersion of the magnetic flux, respectively. In addition, it provides the percentage voltage drop caused by the equipment when it feeds full load. This test determines the value of the transformer's percentage impedance.

In this test, the applied voltage is small compared to the rated voltage. In these circumstances, the current of the magnetizing branch is very small compared to that one which flows through the short circuit and, therefore, the magnetizing branch can be neglected. So, it is assumed that the equivalent electric circuit of Figure 2.

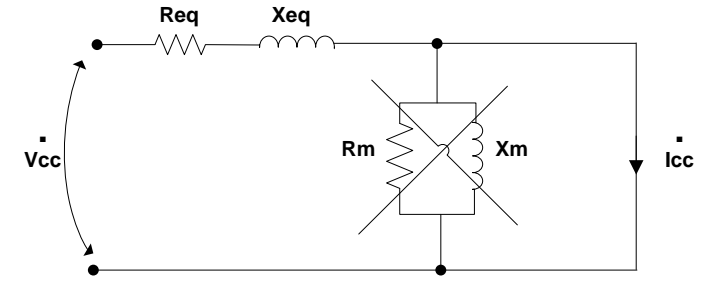

Figure 2. Equivalent Circuit of the Short-Circuit Testing.

The equivalent electrical resistance $R_{e q}$ and the equivalent inductive reactance $X_{e q}$ correspond, respectively, to the sum of the resistances and dispersion reactances of the primary and secondary windings referred to the primary. The percent impedance of the transformer is given by $Z_{e q}$, information contained on the transformer nameplate.

$$
\begin{gathered}
R_{e q}=\frac{P_{c c}}{I_{c c}^{2} \cdot Z_{B}}[p u] \rightarrow \operatorname{Req}=\frac{P_{c c}}{S_{B}}[p u] \\
Z_{e q}=\frac{V_{c c}}{I_{B} \cdot Z_{B}}[p u]=\frac{V_{c c}}{V_{B}}[p u] . \\
X_{e q}=\sqrt{Z_{e q}^{2}-R_{e q}^{2}}[p u] .
\end{gathered}
$$

Where:

$$
\begin{array}{lll}
P_{c c} & - & \text { Short-Circuit Power [W]. } \\
I_{c c} & - & \text { Short-Circuit Current [A]. } \\
V_{c c} & - & \text { Short-Circuit Voltage [V]. }
\end{array}
$$

The resistance Req should have its value corrected for the transformer operating temperature, since, most likely at the time of the test, the equipment is out of its operating temperature which affects the electrical resistance of the windings, because it varies with the temperature. The correction is foreseen in the technical norm NBR5380 / 1993 [3], according (4).

$$
R_{e q}^{\prime}=R_{e q} \cdot \frac{\theta_{1}+\propto}{\theta_{2}+\propto}
$$

Being:

$$
\begin{array}{rll}
\theta_{1} & - & \text { Reference temperature }\left[{ }^{\circ} \mathrm{C}\right] \\
\theta_{2} & - & \text { Surrounding medium temperature }\left[{ }^{\circ} \mathrm{C}\right] \\
\propto & - & \text { Temperature coefficient }(234.5 \text { for copper } \\
& & \text { and } 224 \text { for aluminum })
\end{array}
$$

The no-load test is performed by applying pure sinewave voltage of nominal rated value to the rated frequency of the equipment [2]. Voltage, current and power are measured, thus enabling the calculation of the magnetizing branch parameters, which represents the hysteresis and Foucault (parasitic currents) losses.

Unlike the traditional transformer models, in this article, we chose to represent the transformer according to Figure 3. It is observed that the equivalent impedance, obtained by the short-circuit test is divided into two parts. These parts are identical in [pu]. This option results in more accurate studies of the magnetizing current impact 
on the electrical power systems, as it does not neglect the voltage drop of the primary winding.

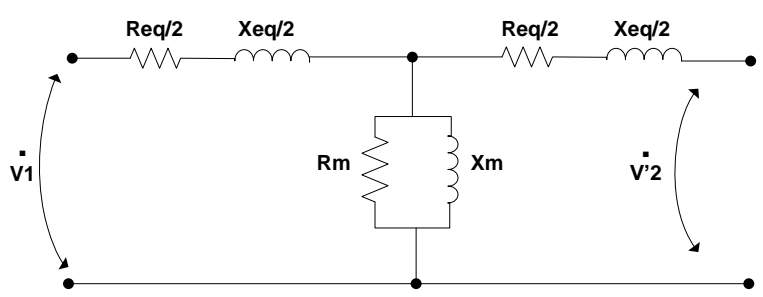

Figure 3. Full Equivalent Circuit.

To obtain the parallel branch, the voltage drop in the primary series impedance caused by the circulation of the no-load current is considered. This is one of the peculiarities of the modeling presented in this article.

$$
\begin{gathered}
\dot{V}_{0}=V_{n}-\left(\frac{R_{e q}}{2}+j \frac{R X_{e q}}{2}\right) \cdot \dot{I}_{0}[V] \\
R_{m}=\frac{\dot{V}_{0}^{2}}{P_{0}-\frac{R_{e q} \cdot \dot{I}_{0}^{2}}{2}}[p u]
\end{gathered}
$$

The no-load current along with the resulting power factor $\left(f p_{o}\right)$, allows the magnetization reactance calculation $\left(X_{m}\right)$.

$$
\begin{gathered}
\dot{I}_{0}=I_{0} \cdot \cos \phi_{o}+j I_{0} \cdot \operatorname{sen} \phi_{o}[A] \\
f p_{o}=\cos \phi_{o}=\frac{P_{0}}{V_{n} \cdot I_{0}} \\
X_{m}=\frac{V_{0}}{I o \cdot \operatorname{sen} \phi_{o}}[\Omega]=\frac{I_{0}}{I o \cdot \operatorname{sen} \phi_{o} \cdot Z_{B}}[p u]
\end{gathered}
$$

Thus, the equivalent admittances of the primary, secondary and magnetization are:

$$
\begin{aligned}
& \dot{Y}_{1}=\dot{Y}_{2}=\frac{2}{R_{e q}+j X_{e q}}[p u] \\
& \dot{Y}_{m}=\frac{R_{m}+j X_{m}}{j\left(R_{m}+X_{m}\right)}[p u]
\end{aligned}
$$

\section{Three-phase Transformer Matrix}

The admittance matrix of the three-phase transformer, for each winding, is represented by (12).

$$
\left[\dot{Y}_{\mathrm{abcn}}\right]=\left[\begin{array}{llll}
\dot{Y}_{a a} & \dot{Y}_{a b} & \dot{Y}_{a c} & \dot{Y}_{a n} \\
\dot{Y}_{b a} & \dot{Y}_{b b} & \dot{Y}_{b c} & \dot{Y}_{b n} \\
\dot{Y}_{c a} & \dot{Y}_{c b} & \dot{Y}_{c c} & \dot{Y}_{c n} \\
\dot{Y}_{n a} & \dot{Y}_{n b} & \dot{Y}_{n c} & \dot{Y}_{n n}
\end{array}\right]
$$

The transfer matrix between the primary busbar (index 1) and the secondary busbar (index 2) of a three-phase transformer with two windings $\left(\left[\dot{Y}_{12}\right]\right)$ is constituted by four primary submatrices that correspond to the primary $\left(\left[\dot{Y}_{p p}\right]\right)$, the secondary $\left(\left[\dot{Y}_{s S}\right]\right)$, and the couplings between both $\left(\left[\dot{Y}_{p s}\right]\right.$ and $\left.\left[\dot{Y}_{s p}\right]\right)$.

$$
\left[\dot{Y}_{12}\right]=\left[\begin{array}{ll}
{\left[\dot{Y}_{p p}\right]} & {\left[\dot{Y}_{p s}\right]} \\
{\left[\dot{Y}_{s p}\right]} & {\left[\dot{Y}_{s s}\right]}
\end{array}\right]
$$

To represent the magnetization branch in three-phase modeling, a dummy bar was chosen to be created between the primary and the secondary, similar to the single-phase modeling. However, in this case, a three-phase transformer (without the magnetization branch) is inserted between the primary and the dummy bar, the same occurs between the dummy bar and the secondary bar, as shown in Figure 4. The magnetizing branch is inserted in the form of load to the dummy bar.

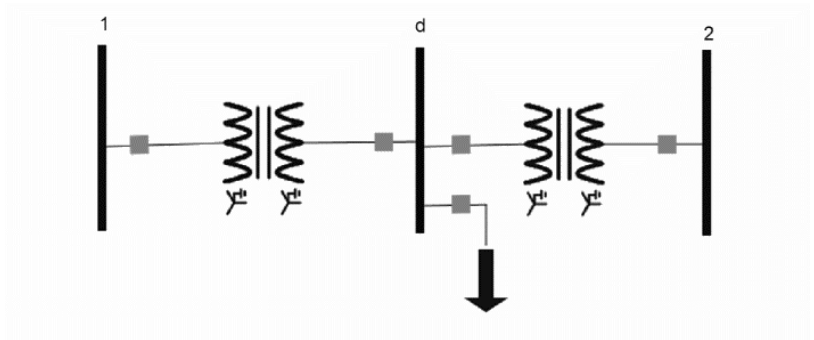

Figure 4. Three-phase transformer modeling.

By using this methodology, the transfer matrix between the primary and secondary results in a matrix of order $12 \times 12$. This one will be formed from submatrices as shown by (14), where the index $d$ indicates the dummy busbar.

$$
\left[\dot{Y}_{12}\right]=\left[\begin{array}{ccc}
{\left[\dot{Y}_{p p}\right]} & {\left[\dot{Y}_{p d}\right]} & {\left[\dot{Y}_{p s}\right]} \\
{\left[\dot{Y}_{d p}\right]} & {\left[\dot{Y}_{d d}\right]} & {\left[\dot{Y}_{d s}\right]} \\
- & {\left[\dot{Y}_{s d}\right]} & {\left[\dot{Y}_{s s}\right]}
\end{array}\right]
$$

It should be noted that the connection of the secondary of the transformer between the primary and the dummy bar will always be grounded star. The same occurs for the primary connection of the transformer between the dummy bar and the secondary bar.

The magnetization branch is modeled in the form of a load, also, connected in a grounded star. Thus, the dummy busbar always has a connection to the reference (ground). This option aims to minimize convergence problems in load flow algorithms when in the presence of ungrounded connections, such as Delta and isolated star connections.

Therefore, the submatrices $\left[\dot{Y}_{d p}\right],\left[\dot{Y}_{p d}\right],\left[\dot{Y}_{d s}\right] e\left[\dot{Y}_{s d}\right]$ represent the transformers connected between the primarydummy and dummy-secondary bars, and depend on the connection adopted in the respective windings. The magnetization branch is modeled by the submatrix $\left[\dot{Y}_{d d}\right]$, according to (15).

$$
\left[\dot{Y}_{d d}\right]=\left[\begin{array}{cccc}
\dot{Y}_{m} & - & - & -\dot{Y}_{m} \\
- & \dot{Y}_{m} & - & -\dot{Y}_{m} \\
- & - & \dot{Y}_{m} & -\dot{Y}_{m} \\
-\dot{Y}_{m} & -\dot{Y}_{m} & -\dot{Y}_{m} & 3 \dot{Y}_{m}
\end{array}\right]
$$


To insert the primary and secondary transformer into the $\left(\left[\dot{Y}_{12}\right]\right)$, will depend on the type of connection. Excluding the zigzag connection, four submatrices are sufficient to represent the other primary and secondary connections.

The sub-matrices should be corrected according to the voltage changes due to the type of connection. The following table translates these changes.

Table 1 - Connections Types

\begin{tabular}{|c|c|c|c|}
\hline Connection & {$\left[Y_{P P}\right]$} & {$\left[Y_{S S}\right]$} & {$\left[Y_{P S}\right],\left[Y_{S P}\right]$} \\
\hline $\mathrm{Y}_{\mathrm{T}}-\mathrm{Y}_{\mathrm{T}}$ & {$\left[Y_{I}\right]$} & {$\left[Y_{I}\right]$} & $-\left[Y_{I}\right]$ \\
\hline $\mathrm{Y}_{\mathrm{T}}-\mathrm{Y}$ & {$\left[Y_{I}\right]$} & {$\left[Y_{I}\right]$} & $-\left[Y_{I}\right]$ \\
\hline $\mathrm{Y}_{\mathrm{T}}-\mathrm{D}$ & {$\left[Y_{I}\right]$} & {$\left[Y_{I I}\right]$} & {$\left[Y_{I I I}\right] / \sqrt{3}$} \\
\hline $\mathrm{Y}_{\mathrm{T}}-\mathrm{Z}$ & {$\left[Y_{I}\right]$} & {$\left[Y_{I V}\right]$} & $-\left[Y_{I}\right]$ \\
\hline $\mathrm{Y}-\mathrm{Y}$ & {$\left[Y_{I}\right]$} & {$\left[Y_{I}\right]$} & $-\left[Y_{I}\right]$ \\
\hline $\mathrm{Y}-\mathrm{Y}_{\mathrm{T}}$ & {$\left[Y_{I}\right]$} & {$\left[Y_{I}\right]$} & $-\left[Y_{I}\right]$ \\
\hline $\mathrm{Y}-\mathrm{D}$ & {$\left[Y_{I I}\right] / 3$} & {$\left[Y_{I I}\right]$} & {$\left[Y_{I I I}\right] / \sqrt{3}$} \\
\hline $\mathrm{Y}-\mathrm{Z}$ & {$\left[Y_{I}\right]$} & {$\left[Y_{I V}\right]$} & $-\left[Y_{I}\right]$ \\
\hline $\mathrm{D}-\mathrm{D}$ & {$\left[Y_{I I}\right] / 3$} & {$\left[Y_{I I}\right] / 3$} & $-\left[Y_{I I}\right] / 3$ \\
\hline $\mathrm{D}-\mathrm{Y}_{\mathrm{T}}$ & {$\left[Y_{I I}\right] / 3$} & {$\left[Y_{I}\right]$} & {$\left[Y_{I}\right]$} \\
\hline $\mathrm{D}-\mathrm{Y}$ & {$\left[Y_{I I}\right] / 3$} & {$\left[Y_{I}\right]$} & {$\left[Y_{I}\right] / \sqrt{3}$} \\
\hline $\mathrm{D}-\mathrm{Z}$ & {$\left[Y_{I I}\right] / 3$} & {$\left[Y_{I V}\right]$} & $-\left[Y_{I}\right]$ \\
\hline $\mathrm{Z}-\mathrm{Y}_{\mathrm{T}}$ & {$\left[Y_{I V}\right]$} & {$\left[Y_{I}\right]$} & $-\left[Y_{I}\right]$ \\
\hline $\mathrm{Z}-\mathrm{Y}$ & {$\left[Y_{I V}\right]$} & {$\left[Y_{I}\right]$} & $-\left[Y_{I}\right]$ \\
\hline $\mathrm{Z}-\mathrm{D}$ & {$\left[Y_{I V}\right]$} & {$\left[Y_{I I}\right] / 3$} & $-\left[Y_{I}\right]$ \\
\hline
\end{tabular}

The submatrices for the correction of voltages are presented in the following equations:

$$
\begin{aligned}
& {\left[\mathrm{Y}_{\mathrm{I}}\right]=\left[\begin{array}{cccc}
1 & 0 & 0 & -1 \\
0 & 1 & 0 & -1 \\
0 & 0 & 1 & -1 \\
-1 & -1 & -1 & 3
\end{array}\right] \text { (16) }\left[\mathrm{Y}_{\mathrm{II}}\right]=\left[\begin{array}{cccc}
2 & -1 & -1 & 0 \\
-1 & 2 & -1 & 0 \\
-1 & -1 & 2 & 0 \\
0 & 0 & 0 & 0
\end{array}\right]} \\
& {\left[\mathrm{Y}_{\mathrm{III}}\right]=\left[\begin{array}{cccc}
-1 & 1 & 0 & 0 \\
0 & -1 & 1 & 0 \\
1 & 0 & -1 & 0 \\
0 & 0 & 0 & 0
\end{array}\right] \text { (18) }\left[\mathrm{Y}_{\mathrm{IV}}\right]=\left[\begin{array}{cccc}
1 & -1 & -1 & -1 \\
-1 & 1 & -1 & -1 \\
-1 & -1 & 1 & -1 \\
-1 & -1 & -1 & 3
\end{array}\right]}
\end{aligned}
$$

As an example, matrix formation will be demonstrated $\left[\dot{Y}_{12}\right]$ of the transformer with the $\mathrm{D}-\mathrm{Y}_{\mathrm{T}}$ connection.

$$
\left[\dot{Y}_{12}\right]=\left[\begin{array}{ccc}
\frac{\left[\dot{Y}_{I I}\right]}{\sqrt{3}} & \frac{\left[\dot{Y}_{I I I}\right]}{\sqrt{3}} & {\left[\dot{Y}_{I}\right]} \\
\frac{\left[\dot{Y}_{I I I}\right]}{\sqrt{3}} & {\left[\dot{Y}_{d d}\right]} & -\left[\dot{Y}_{I}\right] \\
- & -\left[\dot{Y}_{I}\right] & {\left[\dot{Y}_{I}\right]}
\end{array}\right]
$$

The submatrix $\left[\dot{Y}_{d d}\right]$ represents where the magnetization branch will be inserted and the junction between the secondary of the first transformer and the primary of the second transformer, which is the dummy bar.

\section{- Zigzag Connection}

In the Zigzag type connection, the admittance matrix undergoes some changes, in which an algorithm is performed to make changes to this connection.

The terms $K_{1}$ and $K_{2}$ are used to correct the parameters in the matrix $\left[\dot{Y}_{12}^{\prime}\right]$.

$$
\begin{gathered}
K_{1}=\frac{-\sin \alpha}{\sin -120^{\circ}} \\
K_{2}=\frac{(\cos \alpha-\sin \alpha)}{\tan -120^{\circ}}
\end{gathered}
$$

Being $\alpha$ the angle of the parameter.

The matrix $\left[\dot{Y}_{12}^{\prime}\right]$ is multiplied by a new matrix that corrects the parameters according to the angles, shown below:

$$
\left[\begin{array}{cccccccc}
- & - & - & - & k 1 & k 2 & - & - \\
- & - & - & - & - & k 1 & k 2 & - \\
- & - & - & - & k 2 & - & k 1 & - \\
- & - & - & - & - & - & - & - \\
k 1 & - & k 2 & - & \left(k 1^{2}+k 2^{2}\right) & (k 1 . k 2) & (k 1 . k 2) & - \\
k 2 & k 1 & - & - & (k 1 . k 2) & \left(k 1^{2}+k 2^{2}\right) & (k 1 . k 2) & - \\
- & k 2 & k 1 & - & (k 1 . k 2) & (k 1 . k 2) & \left(k 1^{2}+k 2^{2}\right) & - \\
- & - & - & - & - & - & - & -
\end{array}\right]
$$

\section{A. Kron Reduction}

Since the dummy busbar does not bring relevant information to the electrical power systems studies, from the computational point of view it is better that the resulting matrix be reduced to one of order $[8,8]$, representing the equation between primary and secondary. This work is carried out by the so-called Kron Reduction [4]. This mathematical tool allows to "eliminate" bars or passive nodes, that is, those that are connected to loads represented by impedance and that are not directly interconnected to the generating sources [9]. The reduction is generally effected from the following (20).

$$
Y^{\prime} i j=Y i j-\frac{Y i k-Y k j}{Y k k}
$$

Where:

$\mathrm{i}=1,2, \ldots, \mathrm{k}-1, \mathrm{k}+1, \ldots \mathrm{n}, \quad \mathrm{e} \mathrm{j}=1,2, \ldots, \mathrm{k}-1, \mathrm{k}+1, \ldots \mathrm{n}$.

After the Kron reduction, the admittance matrix is summarized in the matrix $Y^{\prime}$.

$$
\left[\begin{array}{ll}
\dot{Y}^{\prime}{ }_{12}
\end{array}\right]=\left[\begin{array}{ll}
{\left[\dot{Y}^{\prime}{ }_{p p}\right]} & {\left[\dot{Y}^{\prime}{ }_{p s}\right]} \\
{\left[\dot{Y}^{\prime}{ }_{s p}\right]} & {\left[\dot{Y}^{\prime}{ }_{s S}\right]}
\end{array}\right]
$$

\section{B. Transformers with grounded neutral}

For transformers with the grounded primary, the ground admittance is added in the submatrix $\dot{Y}_{p p}^{\prime}$, while for ground impedance in the secondary, it is added to the submatrix $\dot{Y}_{s s}^{\prime}$.

\section{Transformers with TAP}

- Transformers with fixed TAP

For transformers with fixed TAP in the primary side the matrix [Y '] goes through the following operation: 


$$
\left[\dot{Y}^{\prime}{ }_{12}\right]=\left[\begin{array}{ll}
\frac{\left[\dot{Y}_{p p}^{\prime}\right]}{T a p^{2}} & \frac{\left[\dot{Y}_{p s}^{\prime}\right]}{T a p} \\
\frac{\left[\dot{Y}_{s p}^{\prime}\right]}{T a p} & {\left[\dot{Y}_{s s}^{\prime}\right]}
\end{array}\right]
$$

For transformers with fixed TAP in the secondary, the matrix [Y '] goes through the following operation:

$$
\left[\dot{Y}_{12}^{\prime}\right]=\left[\begin{array}{cc}
{\left[\dot{Y}_{p p}^{\prime}\right]} & \frac{\left[\dot{Y}_{p s}^{\prime}\right]}{T a p} \\
\frac{\left[\dot{Y}_{s p}^{\prime}\right]}{T a p} & \frac{\left[\dot{Y}_{s s}^{\prime}\right]}{T a p^{2}}
\end{array}\right]
$$

\section{- Three-phase transformers with automatic TAP}

For each interaction of the load flow the tap can be changed according to the voltage to be controlled. Thus, if the desired voltage is not within predetermined limits, the tap is increased by reducing the value according to the value and amount of taps available.

\section{Validation of the Model}

For the validation of the model, tests were performed in no-load and short circuit. The parameters used were: $\mathrm{S}=$ $100 \mathrm{kVA}, \mathrm{P} 0=0.5 \%, \mathrm{I} 0=1 \%, \mathrm{Pcc}=1 \%$ and $\mathrm{Z} \%=3$.

In the short-circuit test, in view of the percent impedance of $3 \%$ of the nominal primary and secondary voltage, an infinite load was placed (very large load compared to the rated load of the transformer) to simulate a short circuit. Load power 10 MVA and power factor 0.85 , with constant impedance.

Table 2 - No-load Test Result of the Different Connections

\begin{tabular}{|c|c|c|c|}
\hline Connection & Expected & Simulated & Angular Lag \\
\hline $\mathrm{Yt}-\mathrm{Yt}$ & $\mathrm{P}=0,5 \mathrm{~kW}$ & $\mathrm{P}=0,5 \mathrm{~kW}$ & $0^{\circ}$ \\
\hline $\mathrm{Yt}-\mathrm{D}$ & $\mathrm{P}=0,5 \mathrm{~kW}$ & $\mathrm{P}=0,5 \mathrm{~kW}$ & $30,01^{\circ}$ \\
\hline $\mathrm{Yt}-\mathrm{Y}$ & $\mathrm{P}=0,5 \mathrm{~kW}$ & $\mathrm{P}=0,5 \mathrm{~kW}$ & $0,01^{\circ}$ \\
\hline $\mathrm{D}-\mathrm{Yt}$ & $\mathrm{P}=0,5 \mathrm{~kW}$ & $\mathrm{P}=0,5 \mathrm{~kW}$ & $-29,99^{\circ}$ \\
\hline $\mathrm{D}-\mathrm{Y}$ & $\mathrm{P}=0,5 \mathrm{~kW}$ & $\mathrm{P}=0,5 \mathrm{~kW}$ & $-29,99^{\circ}$ \\
\hline $\mathrm{D}-\mathrm{D}$ & $\mathrm{P}=0,5 \mathrm{~kW}$ & $\mathrm{P}=0,5 \mathrm{~kW}$ & $-29,99^{\circ}$ \\
\hline $\mathrm{Y}-\mathrm{Yt}$ & $\mathrm{P}=0,5 \mathrm{~kW}$ & $\mathrm{P}=0,5 \mathrm{~kW}$ & $0,01^{\circ}$ \\
\hline $\mathrm{Y}-\mathrm{Y}$ & $\mathrm{P}=0,5 \mathrm{~kW}$ & $\mathrm{P}=0,5 \mathrm{~kW}$ & $0,01^{\circ}$ \\
\hline $\mathrm{Y}-\mathrm{D}$ & $\mathrm{P}=0,5 \mathrm{~kW}$ & $\mathrm{P}=0,5 \mathrm{~kW}$ & $30,01^{\circ}$ \\
\hline $\mathrm{Yt}-\mathrm{Z}\left(10^{\circ}\right)$ & $\mathrm{P}=0,5 \mathrm{~kW}$ & $\mathrm{P}=0,5 \mathrm{~kW}$ & $10,01^{\circ}$ \\
$\mathrm{Yt}-\mathrm{Z}\left(15^{\circ}\right)$ & $\mathrm{P}=0,5 \mathrm{~kW}$ & $\mathrm{P}=0,5 \mathrm{~kW}$ & $15,01^{\circ}$ \\
$\mathrm{Yt}-\mathrm{Z}\left(20^{\circ}\right)$ & $\mathrm{P}=0,5 \mathrm{~kW}$ & $\mathrm{P}=0,5 \mathrm{~kW}$ & $20,01^{\circ}$ \\
\hline $\mathrm{Y}-\mathrm{Z}\left(10^{\circ}\right)$ & $\mathrm{P}=0,5 \mathrm{~kW}$ & $\mathrm{P}=0,5 \mathrm{~kW}$ & $10,01^{\circ}$ \\
$\mathrm{Y}-\mathrm{Z}\left(15^{\circ}\right)$ & $\mathrm{P}=0,5 \mathrm{~kW}$ & $\mathrm{P}=0,5 \mathrm{~kW}$ & $15,01^{\circ}$ \\
$\mathrm{Y}-\mathrm{Z}\left(20^{\circ}\right)$ & $\mathrm{P}=0,5 \mathrm{~kW}$ & $\mathrm{P}=0,5 \mathrm{~kW}$ & $20,01^{\circ}$ \\
\hline $\mathrm{D}-\mathrm{Z}\left(10^{\circ}\right)$ & $\mathrm{P}=0,5 \mathrm{~kW}$ & $\mathrm{P}=0,5 \mathrm{~kW}$ & $-19,99^{\circ}$ \\
$\mathrm{D}-\mathrm{Z}\left(15^{\circ}\right)$ & $\mathrm{P}=0,5 \mathrm{~kW}$ & $\mathrm{P}=0,5 \mathrm{~kW}$ & $-14,99^{\circ}$ \\
$\mathrm{D}-\mathrm{Z}\left(20^{\circ}\right)$ & $\mathrm{P}=0,5 \mathrm{~kW}$ & $\mathrm{P}=0,5 \mathrm{~kW}$ & $-9,99^{\circ}$ \\
\hline $\mathrm{Z}\left(10^{\circ}\right)-\mathrm{Yt}$ & $\mathrm{P}=0,5 \mathrm{~kW}$ & $\mathrm{P}=0,5 \mathrm{~kW}$ & $-9,99^{\circ}$ \\
$\mathrm{Z}\left(15^{\circ}\right)-\mathrm{Yt}$ & $\mathrm{P}=0,5 \mathrm{~kW}$ & $\mathrm{P}=0,5 \mathrm{~kW}$ & $-14,99^{\circ}$ \\
$\mathrm{Z}\left(20^{\circ}\right)-\mathrm{Yt}$ & $\mathrm{P}=0,5 \mathrm{~kW}$ & $\mathrm{P}=0,5 \mathrm{~kW}$ & $-19,99^{\circ}$ \\
\hline $\mathrm{Z}\left(10^{\circ}\right)-\mathrm{Y}$ & $\mathrm{P}=0,5 \mathrm{~kW}$ & $\mathrm{P}=0,5 \mathrm{~kW}$ & $-9,99^{\circ}$ \\
$\mathrm{Z}\left(15^{\circ}\right)-\mathrm{Y}$ & $\mathrm{P}=0,5 \mathrm{~kW}$ & $\mathrm{P}=0,5 \mathrm{~kW}$ & $-14,99^{\circ}$ \\
$\mathrm{Z}\left(20^{\circ}\right)-\mathrm{Y}$ & $\mathrm{P}=0,5 \mathrm{~kW}$ & $\mathrm{P}=0,5 \mathrm{~kW}$ & $-19,99^{\circ}$ \\
\hline $\mathrm{Z}\left(10^{\circ}\right)-\mathrm{D}$ & $\mathrm{P}=0,5 \mathrm{~kW}$ & $\mathrm{P}=0,5 \mathrm{~kW}$ & $20,01^{\circ}$ \\
$\mathrm{Z}\left(15^{\circ}\right)-\mathrm{D}$ & $\mathrm{P}=0,5 \mathrm{~kW}$ & $\mathrm{P}=0,5 \mathrm{~kW}$ & $15,01^{\circ}$ \\
$\mathrm{Z}\left(20^{\circ}\right)-\mathrm{D}$ & $\mathrm{P}=0,5 \mathrm{~kW}$ & $\mathrm{P}=0,5 \mathrm{~kW}$ & $10,01^{\circ}$ \\
\hline
\end{tabular}

For the zigzag connection tests were performed at three different angles $10^{\circ}, 15^{\circ}$ and $20^{\circ}$. As can be seen from Table 2, there was no error in the no-load assay on the different types of connections. The expected value was the same as the simulated, thus validating the model.

In Table 2 it is also possible to note the angular lag in the three-phase electrical voltages according to each type of connection.

In Table 3, it is possible to notice that as in the No-load test did not present errors, the expected value was the same as the simulated one. The model that presents the neutral and the branch of magnetization can be validated.

Table 3 - Short-Circuit Test Result of the Different Connections

\begin{tabular}{|c|c|c|}
\hline Connection & Expected & Simulated \\
\hline $\mathrm{Yt}-\mathrm{Yt}$ & $\mathrm{P}=3,0 \mathrm{~kW}$ & $\mathrm{P}=3,0 \mathrm{~kW}$ \\
\hline $\mathrm{Yt}-\mathrm{D}$ & $\mathrm{P}=3,0 \mathrm{~kW}$ & $\mathrm{P}=3,0 \mathrm{~kW}$ \\
\hline $\mathrm{Yt}-\mathrm{Y}$ & $\mathrm{P}=3,0 \mathrm{~kW}$ & $\mathrm{P}=3,0 \mathrm{~kW}$ \\
\hline $\mathrm{D}-\mathrm{Yt}$ & $\mathrm{P}=3,0 \mathrm{~kW}$ & $\mathrm{P}=3,0 \mathrm{~kW}$ \\
\hline $\mathrm{D}-\mathrm{Y}$ & $\mathrm{P}=3,0 \mathrm{~kW}$ & $\mathrm{P}=3,0 \mathrm{~kW}$ \\
\hline $\mathrm{D}-\mathrm{D}$ & $\mathrm{P}=3,0 \mathrm{~kW}$ & $\mathrm{P}=3,0 \mathrm{~kW}$ \\
\hline $\mathrm{Y}-\mathrm{Yt}$ & $\mathrm{P}=3,0 \mathrm{~kW}$ & $\mathrm{P}=3,0 \mathrm{~kW}$ \\
\hline $\mathrm{Y}-\mathrm{Y}$ & $\mathrm{P}=3,0 \mathrm{~kW}$ & $\mathrm{P}=3,0 \mathrm{~kW}$ \\
\hline $\mathrm{Y}-\mathrm{D}$ & $\mathrm{P}=3,0 \mathrm{~kW}$ & $\mathrm{P}=3,0 \mathrm{~kW}$ \\
\hline $\mathrm{Yt}-\mathrm{Z}\left(10^{\circ}\right)$ & $\mathrm{P}=3,0 \mathrm{~kW}$ & $\mathrm{P}=3,0 \mathrm{~kW}$ \\
$\mathrm{Yt}-\mathrm{Z}\left(15^{\circ}\right)$ & $\mathrm{P}=3,0 \mathrm{~kW}$ & $\mathrm{P}=3,0 \mathrm{~kW}$ \\
$\mathrm{Yt}-\mathrm{Z}\left(20^{\circ}\right)$ & $\mathrm{P}=3,0 \mathrm{~kW}$ & $\mathrm{P}=3,0 \mathrm{~kW}$ \\
\hline $\mathrm{Y}-\mathrm{Z}\left(10^{\circ}\right)$ & $\mathrm{P}=3,0 \mathrm{~kW}$ & $\mathrm{P}=3,0 \mathrm{~kW}$ \\
$\mathrm{Y}-\mathrm{Z}\left(15^{\circ}\right)$ & $\mathrm{P}=3,0 \mathrm{~kW}$ & $\mathrm{P}=3,0 \mathrm{~kW}$ \\
$\mathrm{Y}-\mathrm{Z}\left(20^{\circ}\right)$ & $\mathrm{P}=3,0 \mathrm{~kW}$ & $\mathrm{P}=3,0 \mathrm{~kW}$ \\
\hline $\mathrm{D}-\mathrm{Z}\left(10^{\circ}\right)$ & $\mathrm{P}=3,0 \mathrm{~kW}$ & $\mathrm{P}=3,0 \mathrm{~kW}$ \\
$\mathrm{D}-\mathrm{Z}\left(15^{\circ}\right)$ & $\mathrm{P}=3,0 \mathrm{~kW}$ & $\mathrm{P}=3,0 \mathrm{~kW}$ \\
$\mathrm{D}-\mathrm{Z}\left(20^{\circ}\right)$ & $\mathrm{P}=3,0 \mathrm{~kW}$ & $\mathrm{P}=3,0 \mathrm{~kW}$ \\
\hline $\mathrm{Z}\left(10^{\circ}\right)-\mathrm{Yt}$ & $\mathrm{P}=3,0 \mathrm{~kW}$ & $\mathrm{P}=3,0 \mathrm{~kW}$ \\
$\mathrm{Z}\left(15^{\circ}\right)-\mathrm{Yt}$ & $\mathrm{P}=3,0 \mathrm{~kW}$ & $\mathrm{P}=3,0 \mathrm{~kW}$ \\
$\mathrm{Z}\left(20^{\circ}\right)-\mathrm{Yt}$ & $\mathrm{P}=3,0 \mathrm{~kW}$ & $\mathrm{P}=3,0 \mathrm{~kW}$ \\
\hline $\mathrm{Z}\left(10^{\circ}\right)-\mathrm{Y}$ & $\mathrm{P}=3,0 \mathrm{~kW}$ & $\mathrm{P}=3,0 \mathrm{~kW}$ \\
$\mathrm{Z}\left(15^{\circ}\right)-\mathrm{Y}$ & $\mathrm{P}=3,0 \mathrm{~kW}$ & $\mathrm{P}=3,0 \mathrm{~kW}$ \\
$\mathrm{Z}\left(20^{\circ}\right)-\mathrm{Y}$ & $\mathrm{P}=3,0 \mathrm{~kW}$ & $\mathrm{P}=3,0 \mathrm{~kW}$ \\
\hline $\mathrm{Z}\left(10^{\circ}\right)-\mathrm{D}$ & $\mathrm{P}=3,0 \mathrm{~kW}$ & $\mathrm{P}=3,0 \mathrm{~kW}$ \\
$\mathrm{Z}\left(15^{\circ}\right)-\mathrm{D}$ & $\mathrm{P}=3,0 \mathrm{~kW}$ & $\mathrm{P}=3,0 \mathrm{~kW}$ \\
$\mathrm{Z}\left(20^{\circ}\right)-\mathrm{D}$ & $\mathrm{P}=3,0 \mathrm{~kW}$ & $\mathrm{P}=3,0 \mathrm{~kW}$ \\
\hline
\end{tabular}

- Fixed TAP

In order to carry out the test, simulated the system corresponding to Figure 5 that has: a voltage source, two bars (bar 1 of $13.8 \mathrm{kV}$ and bar 2 of $0.380 \mathrm{kV}$ ), a transformer with $\mathrm{S}=112.5 \mathrm{kVA}$, and a load with $\mathrm{S}=112.5$ $\mathrm{kVA}$ and power factor of 0.85 .

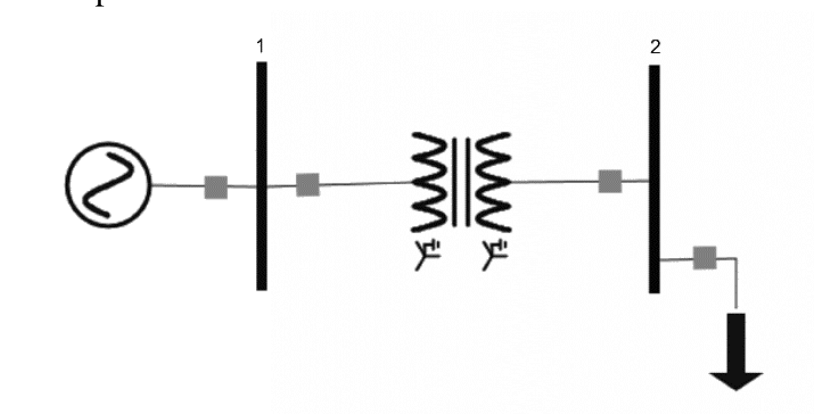

Figure 5. System for simulation with different TAPs 
The first simulation was performed without change in the TAP, it was observed that the voltage in the secondary side dropped from $0.380 \mathrm{kV}$ to $0.350 \mathrm{kV}$ due to the presence of the load.

For the Fixed TAP test in the primary a percentage of TAP 90\% was placed, it was possible to observe in Table 4 that the voltage returned to $0,380 \mathrm{kV}$. The same procedure was performed for Fixed TAP in the secondary with a percentage of $110 \%$, obtaining the same result. Thus, it can be concluded that the transformer with Fixed TAP was validated.

Table 4 - Test Results with different TAPs

\begin{tabular}{|c|c|c|}
\hline Sem TAP & TAP Primário & TAP Secundário \\
\hline $0,35 \mathrm{kV}$ & $0,38 \mathrm{kV}$ & $0,38 \mathrm{kV}$ \\
\hline
\end{tabular}

\section{- Automatic TAP}

For the Automatic TAP test, the same system of Figure 6 was used with the same parameters.

Without the automatic TAP the voltage in busbar 2 was from $0.380 \mathrm{KV}$ to $0.350 \mathrm{KV}$ becoming unfeasible. When it was added, it took 3 TAPs with a $2 \%$ step to raise the voltage to 0.370 . Thus, it can be concluded that the transformer with Automatic TAP has been validated.

\section{Conclusion}

In this article was proposed a new methodology to model three-phase transformers, in which the magnetizing and neutral branches are included for the different types of connections. This type of method was performed to represent more realistically the electrical system, unlike the other studies that are found in the literature.

The results obtained through the simulations observed the efficiency of the proposed method. The different types of connections converged and there was no increase in computational time of solution.

For future work, convergence in an 18-bar system and the number of interactions required will be studied. In addition, the computational time of the different methods will be compared.

\section{Acknowledgement}

We thank the Laboratory of Energy Efficiency (LEFE) of the Federal University of Uberlandia for the support that facilitated the research and the help in the writing of this article. $\mathrm{CNPq}$ for financial support.

\section{References}

[1] C. A. Sanguedo, "Determinação das perdas técnicas dos transformadores de distribuição, com dielétrico líquido, instalados nas empresas concessionárias de energia no Brasil," 2008.

[2] S. J. Chapman, Fundamentos de Máquinas Elétricas, no. c. 2013

[3] "ABNT, NBR. 5380 Transformadores de Potência-Método de Ensaio. 1993.," 1993.
[4] STEVENSON, W. D. Elementos de Análise de Sistemas de Potência. 2 Ed. Editora MacGraw-Hill do Brasil. São Paulo, 1979.

[5] ARRILlaGA, J; ARNOLD, C.P. Computer Analysis of Power Systems

[6] CAPARÓ, José Luis C., Modelagem de Transformadores de Distribuição para Aplicação em Algoritmos de Fluxo de Potência Trifásico. 2005. 158f. Dissertação de Mestrado Universidade Estadual Paulista "Júlio de Mesquita Filho", Ilha Solteira, 2005.

[7] DARIO E. RODAS R. Distribuition Transformers Modeling With Angular Displacement - Actual Values And Per Unit Analysis. Revista Controle \& Automação, Vol. 18, $\mathrm{n}^{\circ} 4$, Outubro, Novembro e Dezembro 2007.

[8] JUNIOR, Antonio Rubens Baran. Fluxo de Potência Ótimo Trifásico.2013. 147f. Dissertação de Mestrado Universidade Federal do Paraná, Curitiba, 2013.

[9] MAMDOUH ABDEL-AKHER. Implementation of threephase transformer model in radial load-flow analysis. Ain Shams Engineering Journal. 2013. 4. 65-73.

[10]SILVA, Fabrício Luiz. Modelagem de Transformadores Trifásicos de Distribuição para Estudos de Fluxo de Potência. 2004. 99f. Dissertação de Mestrado Universidade Federal de Juiz de Fora, Juiz de Fora, 2004

[11] SILVA, Sérgio F. P. Simulador de Sistema Elétricos de Potência, versão 2018. 